\title{
In vitro propagation of Maytenus ilicifolia (Celastraceae) as potential source for antitumoral and antioxidant quinomethide triterpenes production. A rapid quantitative method for their analysis by reverse-phase high-performance liquid chromatography
}

\author{
Waldemar Buffa Filho, ${ }^{a}$ Vanderlan da Silva Bolzani, ${ }^{a}$ Maysa Furlan*a, Sarazete Izidia Vaz \\ Pereira, ${ }^{b}$ Ana Maria Soares Pereira, ${ }^{b}$ and Suzelei Castro França ${ }^{b}$ \\ ${ }^{a}$ Núcleo de Bioensaio, Biossíntese e Ecofisiologia de Produtos Naturais - Instituto de Química, \\ Universidade Estadual Paulista, CP. 355, 14801-970, Araraquara-SP, Brazil \\ ${ }^{b}$ Departamento de Biotecnologia, UNAERP, 14096-380, Ribeirão Preto-SP, Brazil \\ E-mail: maysaf@iq.unesp.br
}

\section{Dedicated to Professor Otto Gottlieb on his $85^{\text {th }}$ anniversary}

(received 30 Jan 04; accepted 14 Sep 04; published on the web 19 Sep 04)

\begin{abstract}
Cell culture of Maytenus ilicifolia were established in order to produce and to quantify the antitumoral and antioxidant quinonemethide triterpenes. In vitro calli were induced from leaf explants of native plants and cultured in semi-solid medium under controlled conditions of humidity, temperature and photoperiod. The quinonemethide triterpenes showed maximum accumulation in the logarithmic phase growth of the cell culture. A rapid, sensitive and reliable reverse-phase HPLC method was used for quantitative determination of the antitumoral and antioxidant quinonemethide triterpenes, 22 $\beta$-hydroxymaytenin and maytenin in callus of Maytenus ilicifolia. Well resolved peaks with good detection response and linearity in the range $1.0-100 \mu \mathrm{g} / \mathrm{mL}$ were obtained. This quantitative work was performed by an external standard method.
\end{abstract}

Keywords: Maytenus ilicifolia, in vitro system, Celastraceae, quinonemethide triterpenes, reverse-phase high-performance liquid chromatography, quantitative determination

\section{Introduction}

Plants produce a wide variety of so called secondary metabolites. These compounds play a role in the survival of the plant in its ecosystem and also are involved in resistance against pests and diseases, attraction of pollinators and interaction with symbiotic microorganisms. Besides the importance for the plant itself, a number of secondary metabolites isolated from plants are being 
commercially exploited as fine chemicals such as drugs, dyes, flavours, fragrances and insecticides. Many pharmaceuticals are produced from plants such as L-DOPA, morphine, codeine, reserpine and the anticancer drugs vincristine, vinblastine and taxol. Some of these secondary metabolites are quite expensive because of their low abundance in the plant, often less than $1 \%$ of the total carbon, or storage usually occurring in dedicated cells or organs. The evolving commercial importance of secondary metabolite has led, in recent years, led scientists and biotechnologists to consider plant cell, tissue and organ cultures as an alternative way to produce the corresponding secondary metabolites. This progress has notably concerned knowledge of enzyme activities and regulation of biosynthetic pathways. ${ }^{1,2,3,4,5,6}$ Besides, some studies employing biotechnology have lead to the biodiversity preservation, because with the adventus of the cell tissue culture technology was possible to establish new plantlets and cell culture in laboratory conditions. The Celastraceae family has shown the accumulation of an interesting class of bioactive compounds, the quinonemethide triterpenes. ${ }^{7,8}$ These triterpenes have been intensively studied by several important research groups due their biological activities, such as antitumoral, antimicrobial, antibiotic and antioxidant. 9,10,11,12,13,6 The genus Maytenus, of Celastraceae, was selected among 200 species as a putative matrix to develop the in vitro system with the objective of improving the production and to obtain a useful model system for studying the biosynthesis of these valuable compounds. ${ }^{14,8,15}$ We closely monitored growth parameters such as length of lag, of log phases, and growth speed during the log phase, for each of the different callus lines obtained from Maytenus ilicifolia (Celastraceae) and their capacity for producing quinonemethides. Cell tissues growth curve demonstrated that the high yielding of the compounds was at the logarithmic phase. Compared to cell growth kinetics, which is usually exponential curve, most of secondary metabolites are produced during the plateau phase, where the carbon allocation is mainly distributed for primary metabolism (building of cell structures and respiration) when growth is very active. The quinonemethide production during the early stage can be explained by growth-associated with the undifferentiated cells. This finding was corroborated by the determination of the cyclase and P450 oxygenase activities involved in the ciclazation and oxygenation steps ${ }^{8}$ of the quinonemethide biosynthesis using cell free extracts of Maytenus ilicifolia callus in an early stage (Buffa Filho, unpublished data). It also opened the door to the possible use of Maytenus ilicifolia culture for the production of the bioactive quinonemethides maytenin (1) and 22ß-hydroxymaytenin (2) (Figure 1), once their synthesis is highly inducible. This paper reports the increasing production of maytenin and $22 \beta$ hydroxymaytenin in the in vitro system and the application of a reverse-phase HPLC method for their quantification. 


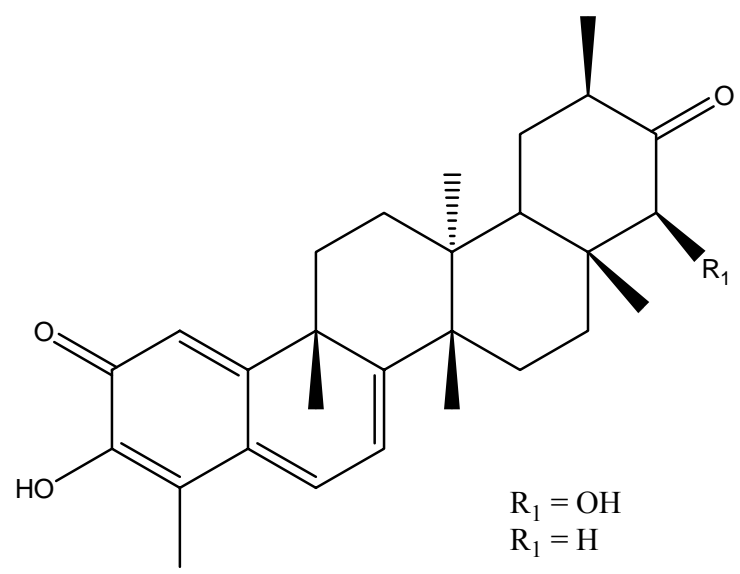

Figure 1. Structures of quinonemethide triterpenoids $22 \beta$-hydroxymaytenin (1) and maytenin (2).

\section{Results and Discussion}

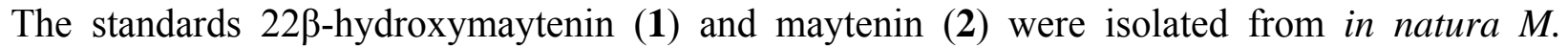
aquifolium, in order to determine the yield of these compounds in the callus extracts. For isolation, the crude hexane fraction of the root barks was submitted to column chromatography followed by preparative TLC. ${ }^{8}$ The two compounds were identified by spectroscopic data, such as UV, IR, MS, ${ }^{1} \mathrm{H}$ and ${ }^{13} \mathrm{C}$ NMR spectra. ${ }^{16,17}$ The compounds $\mathbf{1}$ and $\mathbf{2}$ were quantified in the extracts, by means of analytical RP-HPLC, which gave a good separation of the standards in a run time of $15 \mathrm{~min}$. The chromatogram of a mixture of the standards $\mathbf{1}$ and $\mathbf{2}$ is shown in Figure 4. The resolution and the standard deviation of the detector response for compounds $\mathbf{1}$ and $\mathbf{2}$ were $\mathrm{R}=0.9997$ and $\mathrm{SD}=38 \times 10^{3}$ and $\mathrm{R}=0.9998$ and $\mathrm{SD}=39 \times 10^{4}$, respectively, showing a good linearity and sensitivity of the detector in the measuring range. The detection limits for $\mathbf{1}$ and 2 were $0.0005 \mathrm{ng}$ and $0.0003 \mathrm{ng}$, respectively. Representative chromatograms of callus from M. ilicifolia (growth curve) (Figure 5) showed an increasing of concentration of 22 $\beta$ hydroxymaytenin (1) and maytenin (2) at the early stages of the growth curve followed by a decreasing at the others (Figures. 2 and 3). The callus was able to accumulate the triterpenes 1 and 2 which were detected by their retention times and further confirmed by comparison of the UV peaks with those of the standards at $420 \mathrm{~nm}$. The characteristic retention times for compounds 1 and 2 under the stablished conditions were 3.469 and $4.133 \mathrm{~min}$, respectively (Figure 5). The yields percents of 1 and 2 were expressed in relation to the dry wt (Table 1) of $M$. ilicifolia callus extracts (Table 2). Logarithmic growth began immediately after 8 days (Figure 2), the quinonemethide triterpenes attained a maximun after 8 days of culture (Figure $3 \mathrm{a}$ and $3 \mathrm{~b}$ ). These findings indicate that the production of the quinonemethides at the early stages of the growth curve is extremely important when thinking about extration, isolation and purification. It means, as the products show high concentration at the first two stages of the curve, if inoculated 
high amounts of cell in the medium in a short period of time is possible to obtain the maximum production of the bioactive compounds. In addition, the table 3 shows that the production of these metabolites in cell tissue culture is 100 times higher for $22 \beta$-hydroxymaytenin 1 and 3 times higher for maytenin 2, when compared with data obtained from root bark of M. ilicifolia in natura. ${ }^{15}$

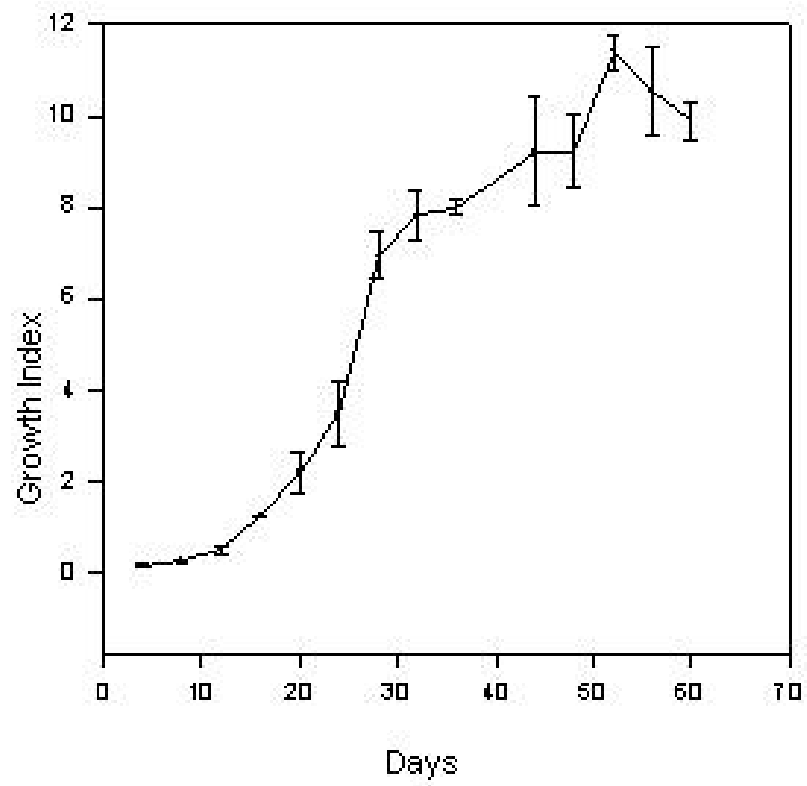

Figure 2. Growth cell tissue culture curve obtained from callus of $M$. ilicifolia.
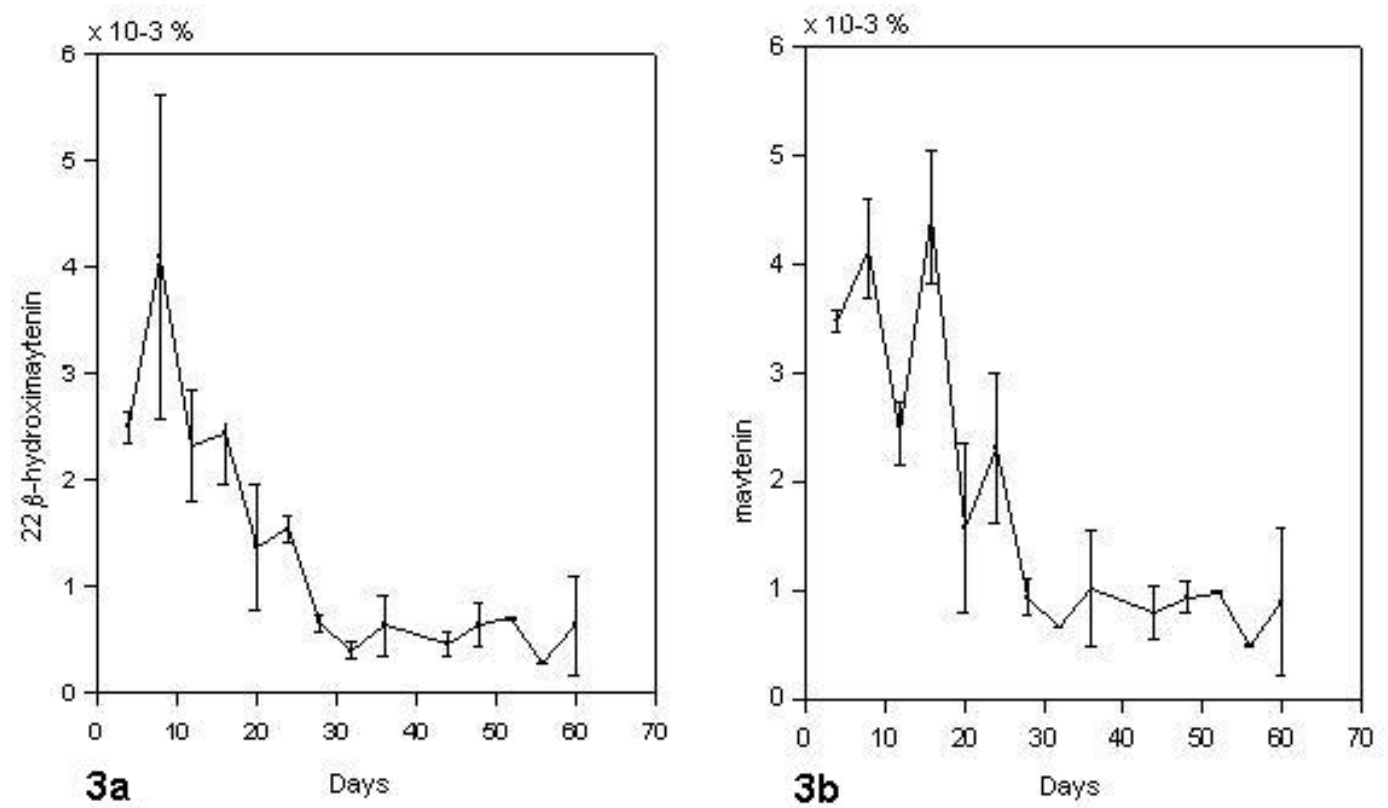

Figure 3. HPLC profile concentration of 22 $\beta$-hydroxymaytenin (1) and maytenin (2) accumulated during 10 week of culture. 


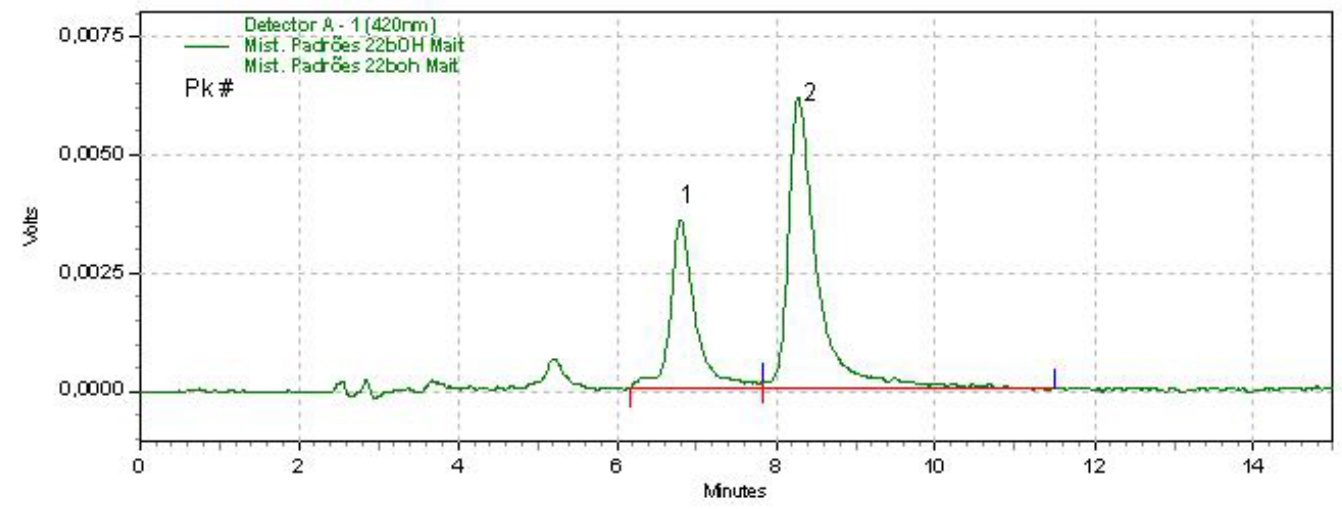

Figure 4. HPLC chromatogram (UV detection at $420 \mathrm{~nm}$ ) of the standards $22 \beta$-hydroxymaytenin (1) and maytenin (2) (for chromatographic protocol see Experimental section).
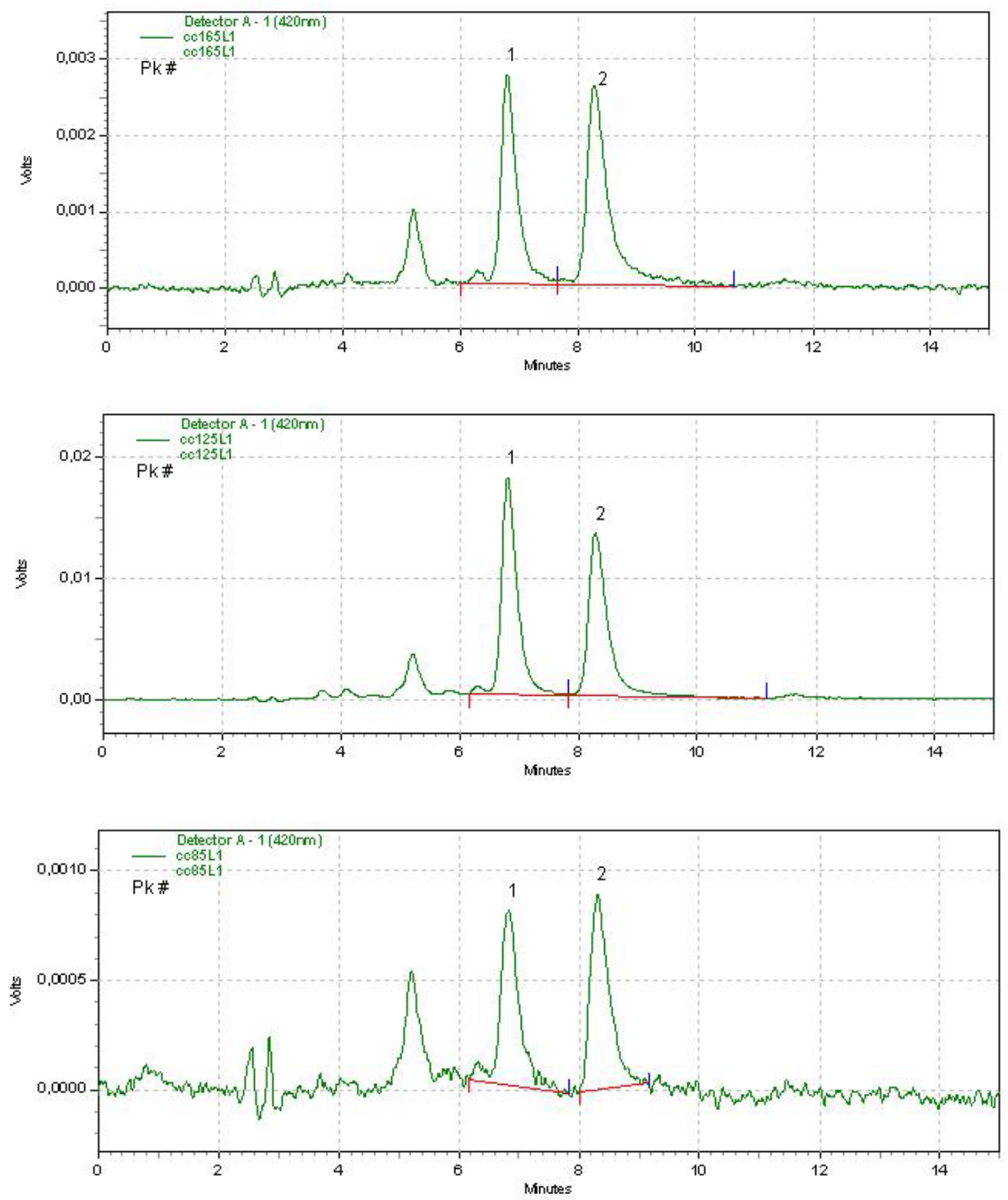

Figure 5. HPLC profile (UV detection at $420 \mathrm{~nm}$ ) of callus extracts at early growth phase. $22 \beta$ hydroxymaytenin (1) and maytenin (2). (for chromatographic protocol see experimental section). 
Table 1. Yield of dried chloroform extracts obtained from callus of Maytenus ilicifolia

\begin{tabular}{|c|c|c|}
\hline Points & Dried weight callus (g) & $\begin{array}{c}\text { Dried weigh of chloroform } \\
\text { extracts }(\mathrm{mg})\end{array}$ \\
\hline 1 & $0.6233 \pm 0.0896$ & $7.1 \pm 1.0$ \\
\hline 2 & $0.7433 \pm 0.0115$ & $11.4 \pm 0.8$ \\
\hline 3 & $0.8633 \pm 0.0643$ & $12.9 \pm 1.0$ \\
\hline 4 & $1.3033 \pm 0.0611$ & $13.4 \pm 1.9$ \\
\hline 5 & $1.9033 \pm 0.0493$ & $19.1 \pm 2.9$ \\
\hline 6 & $1.8700 \pm 0.2551$ & $13.9 \pm 2.3$ \\
\hline 7 & $3.0633 \pm 0.1518$ & $25.0 \pm 2.4$ \\
\hline 8 & $2.9967 \pm 0.0709$ & $26.5 \pm 5.1$ \\
\hline 9 & $3.2633 \pm 0.1007$ & $21.9 \pm 3.3$ \\
\hline 10 & $2.7350 \pm 0.1768$ & $22.7 \pm 2.0$ \\
\hline 11 & $3.4200 \pm 0.1273$ & $18.6 \pm 0.6$ \\
\hline 12 & $3.9500 \pm 0.0424$ & $23.8 \pm 8.9$ \\
\hline 13 & $2.7700 \pm 0.2121$ & $27.2 \pm 3.2$ \\
\hline 14 & $3.1400 \pm 0.4243$ & $23.5 \pm 0.3$ \\
\hline
\end{tabular}


Table 2. Content of quinonemethide derivatives $\mathbf{1}$ and $\mathbf{2}$ in cell tissue culture of Maytenus ilicifolia

\begin{tabular}{|c|c|c|}
\hline \multirow{2}{*}{ Points } & \multicolumn{2}{|c|}{ Composition $^{\mathrm{a}}$ of callus } \\
\hline & 22ß-hydroxymaytenin (1) & Maytenin (2) \\
\hline 1 & $0.0250 \pm 0.00142$ & $0.0035 \pm 0.0001$ \\
\hline 2 & $0.0410 \pm 0.01527$ & $0.0041 \pm 0.0005$ \\
\hline 3 & $0.0232 \pm 0.00519$ & $0.0024 \pm 0.0003$ \\
\hline 4 & $0.0244 \pm 0.00495$ & $0.0044 \pm 0.0007$ \\
\hline 5 & $0.0137 \pm 0.00597$ & $0.0016 \pm 0.0008$ \\
\hline 6 & $0.0154 \pm 0.00120$ & $0.0023 \pm 0.0007$ \\
\hline 7 & $0.0062 \pm 0.00089$ & $0.0009 \pm 0.0002$ \\
\hline 8 & $0.0040 \pm 0.00079$ & $0.0007 \pm 0.0001$ \\
\hline 9 & $0.0063 \pm 0.00292$ & $0.0010 \pm 0.0005$ \\
\hline 10 & $0.0046 \pm 0.00121$ & $0.0007 \pm 0.0002$ \\
\hline 11 & $0.0063 \pm 0.00205$ & $0.0005 \pm 0.0005$ \\
\hline 12 & $0.0070 \pm 0.00013$ & $0.0010 \pm 0.0001$ \\
\hline 13 & $0.0027 \pm 0.00004$ & $0.0005 \pm 0.0001$ \\
\hline 14 & $0.0063 \pm 0.00467$ & $0.0009 \pm 0.0007$ \\
\hline
\end{tabular}

${ }^{a}$ Average and standard deviation of content expressed in (\%) with respect to dry weight of the cell tissue culture. 
Table 3. Comparison of contents of quinonemethide derivatives $\mathbf{1}$ and $\mathbf{2}$ in cell tissue culture (cultured for 60 days) and in natura plant of Maytenus ilicifolia

\begin{tabular}{|c|c|c|}
\hline \multirow[t]{2}{*}{ Standards } & \multicolumn{2}{|c|}{$\begin{array}{l}\text { Composition }^{\mathrm{a}} \text { of maytenin and } \\
22 \beta \text {-hydroxymaytenin }\end{array}$} \\
\hline & Root Bark & Callus \\
\hline 1 & 0,00030 & 0,04097 \\
\hline 2 & 0,00029 & 0,00438 \\
\hline
\end{tabular}

${ }^{a}$ Content expressed in (\%) with respect to dry weight of plant material and cell tissue culture.

\section{Experimental Section}

General Procedures. Materials. The standards 1 and $\mathbf{2}$ were isolated from Maytenus aquifolium and Salacia campestris as described elsewhere ${ }^{8}$. HPLC-grade acetonitrile was purchased from Mallinckrodt (Mallinckrodt Baker, S.A. de C.V. 55320, Xalostoc, Edo. de Méx., México); all solvents and samples were filtered through a $0.2 \mu \mathrm{m}$ nylon membrane (Millipore). Nanopure water (>18 MOhm) was obtained using a Millipore (Millipore Corporation, 80 Ashby Road, Bedford, MA 01730-2271) purifier.

Plant material. Aseptic leaf explants from 8 years old micropropagated plants of $M$. ilicifolia ${ }^{18}$ were inoculated on MS medium ${ }^{19}$ supplemented with $0.4 \mathrm{mg} / \mathrm{L}$ of BAP (6benzilaminopurine) and $0.2 \mathrm{mg} / \mathrm{L}$ of ANA (naftalen acetic acid). After 3 months leaf explants (1 $\mathrm{cm}^{2}$ ) were inoculated on MS ${ }^{19}$ medium supplemented with $1.0 \mathrm{mg} / \mathrm{L}$ of $\mathrm{K}$ (Kinetin) and 1.0 $\mathrm{mg} / \mathrm{L}$ of 2,4-D (2,4-dichlorophenoxy acetic acid). Callus was kept on the same medium for 1 year, subcultured every 30 days. Cell culture was kept on the same medium for 45 days, subcultured for fresh medium must be made after this period. A growth cell tissue culture curve (Figure 2) was obtained in order to verify in which period the metabolites express a maximum of concentration (Figure $3 \mathrm{a}$ and $3 \mathrm{~b}$ ). Callus was kept on the medium as described for 45 days and the start inoculum was $1.0 \pm 0.1 \mathrm{~g}$. The curve had a total of 14 points representing cells collected in period of 4 days each out of 60 days.

Sample preparation. Dried and powdered callus of $M$. ilicifolia were extracted three times with a known volume of chloroform $(100 \mathrm{~mL})$ overnight at room temperature. The fractions were evaporated to dryness and the residues were dissolved in methanol to yield solutions with concentration of $1.0 \mathrm{mg} / \mathrm{mL}-20 \mu \mathrm{L}$ aliquots of these solutions were analysed by HPLC. 
HPLC analysis. A Shimadzu (Shimadzu Corporation Kanda - Nishikicho 1 - chome, Chiyoda $\mathrm{Ku}$, Tokyo 101 - Japan) model LC-10AS chromatographY, coupled to a model SPD-10 UV detector, auto-injector SIL-10A, control system CBM-10A, software Class-LC 10 and equipped with a Phenomenex Luna C18 column $(250 \times 4.6 \mathrm{~mm}$ i. d.; $5 \mu \mathrm{m})$ and pre-column $(20 \times 4.6 \mathrm{~mm}$ i. d.), was employed. Chromatography was carried out under isocratic conditions with acetonitrile: water $(85: 15, \mathrm{v} / \mathrm{v})$ containing $0.1 \%$ acetic acid as the mobile phase at a flow rate of $1 \mathrm{~mL} / \mathrm{min}$. The column was purged with the mobile phase for $3 \mathrm{~min}$, followed by equilibration for $10 \mathrm{~min}$ : the total analytical run time for each sample was $15 \mathrm{~min}$. Spectral data from the UV detector were collected over $15 \mathrm{~min}$ in the 253 - $420 \mathrm{~nm}$ range: the chromatograms were analysed and plotted at $420 \mathrm{~nm}$. The linearity of the detector response and the calibration curve were stablished for compounds $\mathbf{1}$ and 2 by a series of injections of standard solutions within a concentration range of $2.5-50.0 \mu \mathrm{g} / \mathrm{mL}$ (1) and $1.0-50.0 \mu \mathrm{g} / \mathrm{mL}$ (2) using a calculated correlation factor for each standard.

\section{Acknowledgements}

This work was supported by grants from FAPESP (97/10184-7). M Furlan and V. da S. Bolzani thank CNPq for providing them fellowships. W. Buffa Filho also thank CNPq for his scholarship.

\section{References}

1. Zenk, M.H. The chemistry and biology of isoquinoline alkaloids; Philipson, J. D.; Roberts, M. F.; Zenk, M. H., Eds; Springer-Verlag: Berlin and New York, 1980.

2. Luckner, M. Encyclopedia of Plant physiology, New Series; Bell, E. A.; Charlwood, B. V., Eds; Springer-Verlag: Berlin and New York, 1980.

3. Luckner, M., Diettrich, B.; Lerbs, W. Progress on Phytochemistry 1980, 6, 103.

4. Barz, W.; Köster, J. The biochemistry of plants; Academic Press: New York, 1981.

5. Wiermann, R. The biochemistry of plants; Conn, E. E., Ed.; Academic Press: New York, 1981.

6. Conn, E. E. Membranes and compartmentation in the regulation of plants function; Boudet, A. M.; Alibert, G.; Mango, G.; Lea, P. J., Eds.; Oxford Univ. Press: London and New York, 1984.

7. Gunatilaka, A. A. L. Progress in Cheminstry of Organic Natural Products 1996, 67, 1.

8. Corsino, J.; Carvalho, P. R. F.; Kato, M. J.; Oliveira, O. M. M. F.; Araújo, A. R.; Bolzani, V. da S.; França, S. C.; Pereira, A. M. S.; Furlan, M. Phytochemistry 2000, 55, 741.

9. Bavovada, R.; Blasko, G.; Shien, H-L.; Pezzuto, J. M.; Cordell, G. A. Planta Medica 1990, 56,380 . 
10. Ferreira de Santana, C.; Asfora, J. J.; Cortias, C. T. Revista do Instituto de Antibióticos 1971, 11, 37.

11. Gonçalves de Lima, O. et al. Revista do Instituto de Antibióticos 1969, 9, 17.

12. Gonçalves de Lima, O.; De Barros Coelho, J. S.; Weighert, I. L.; D'Albuquerque, D.; De Lima, A.; De M Souza, M. A. Revista do Instituto de Antibioticos 1972, 11, 35.

13. Ngassapa, O.; Soejarto, D. D.; Pezzuto, J. M.; Farnsworth, N. R. Journal of Natural Products 1994, 57, 1.

14. Corsino, J.; Alécio, A. C.; Ribeiro, M. L.; Pereira, A. M. S.; França, S. C.; Furlan, M. Phytochemical Analysis 1998, 9, 245.

15. Buffa Filho, W.; Corsino, J.; Furlan, M.; Pereira, A. M. S.; França, S. C. Phytochemical Analysis 2002, 13, 75.

16. Gunatilaka, A. A. L.; Fernando, C.; Kikuchi, Tezuka Y. Magnetic Resonance Chemistry 1989, 27, 803.

17. Likhitwitaywuid, K.; Bavovada, R.; Lin, L-Z.; Cordell, G. A. Phytochemistry 1993, 34, 759.

18. Pereira, A. M. S.; Moro, J. R.; Cerdeira, R. M. M.; França, S. C. Plant, Cell, Tissue \& Organ Culture 1995, 42, 295.

19. Murashige, T.; Skoog, F. Physiological Plant 1962, 15, 473. 